Pat Hutchings, CARNEGIE FOUNDATION, hutchings@carnegiefoundation.org

Paola Borin, RYERSON UNIVERSITY, borin@ryerson.ca

Linda Keesing-Styles, UNITEC INSTITUTEOFTECHNOLOGY,lkeesing-styles@unitec.ac.nz

Lynn Martin, MCMASTER UNIVERSITY, Martl@mcmaster.ca

Renee Michael, ROCKHURST UNIVERSITY, renee.michael@rockhurst.edu

Lauren Scharff, UNITED STATES AIR FORCE ACADEMY, Lauren.Scharff@usafa.edu

Scott Simkins, NORTH CAROLINA A\&T STATE UNIVERSITY, simkinss@ncat.edu

Ahmed Ismail, MCMASTER UNIVERSITY, ismailae@mcmaster.ca

\title{
The Scholarship of Teaching and Learning in an Age of Accountability: Building Bridges
}

\section{ABSTRACT}

In recent years, as pressures for accountability have increased in higher education, some members of the Scholarship of Teaching and Learning (SoTL) community may worry that the inquiry-based, improvement-focused practices they advocate could be put at risk by easy-to-administer, one-size-fits-all forms of assessment, quality assurance, and administrative control. But while acknowledging both real and perceived tensions between these two movements, we also examine some of the ways and settings in which they are converging, featuring a number of international examples in which external quality and assessment mandates have been employed to support SoTL-like work. We look, too, at the roles that scholars of teaching and learning can play as mediators and brokers between the two movements, helping to translate accountability requirements into opportunities for improvement. In short we argue that these two movements present opportunities for each other. SoTL can contribute to what is, or should be, the central goal of accountability: ensuring and improving the quality of student learning. The accountability movement, for its part, can provide a new context for integrating and valuing SoTL as a force for positive change on campuses and beyond. Taken together, the two approaches can make meaningful contributions to higher learning today. The paper concludes with recommendations to the SoTL community for building bridges between the two movements.

\section{KEYWORDS}

higher education, scholarship of teaching and learning, accountability, quality, improvement

With pressures for accountability on the rise in higher education around the globe, scholars of teaching and learning may well be concerned that the inquiry-based, improvement-focused research they favor will be put at risk by easy-to-administer, onesize-fits-all forms of assessment, quality assurance mandates, and administrative control. 
While these concerns are understandable given the different traditions in which the Scholarship of Teaching and Learning (SoTL) and accountability are rooted, we see a potential for positive synergy between these two movements today. SoTL can contribute to what is, or should be, the central goal of accountability: ensuring and improving the quality of student learning. The accountability movement, for its part, can provide a new context for integrating and valuing SoTL as a force for positive change on campuses and beyond. Taken together, the two approaches can make meaningful contributions to higher education.

The questions for this paper, then, are how these two movements might more closely work together now and in the future, and what the implications of such a partnership might be for SoTL, accountability, and higher education at large. These are, we acknowledge, very broad questions, and our intent is not to answer them fully but to put forth a range of issues and possibilities for further exploration. Our perspective on the topic (in the words of a reviewer of an earlier version of this paper) is "optimistic but not naive." In that spirit, our presentation moves through five sections: (a) growing pressures for accountability in higher education, (b) perceived tensions between accountability and SoTL, (c) promising developments and convergences in both movements, (d) building bridges between them; and, finally, (e) recommendations to the SoTL community.

\section{GROWING PRESSURES FOR ACCOUNTABILITY IN HIGHER EDUCATION}

Historically, higher education institutions gained the trust of those they served based on strong norms and a common identity. The oldest universities (University of Bologna, the University of Paris, Oxford University) invested resources to maintain established reputations as a proxy for trust and quality (Jacobi, Astin, \& Ayala, 1987; Stensaker \& Harvey, 2011). Over the last several decades, however, this public trust in higher education has eroded, with calls for increased accountability worldwide. For example, conservative fiscal policy in the US and UK in the 1980s threatened to reduce public support for higher education while also increasing pressure to "drive up quality" and improve outcomes (Clark, 2009; Newton, 2000). Various forms of performance funding were instituted in the UK (Clark, 2009), in some US states (Banta, 2010), and in Australia (Baird, 2011).

At the same time, new models of quality assurance, efficiency, and continuous improvement developed for manufacturing began to be applied to higher education (Brown \& Lauder, 1996; ISO, 2012; Marchese, 1991). Colleges and universities were hearing about quality assurance, quality improvement, and total quality management. As a result, in a number of countries, "quality councils" were created to think more systematically about how to increase and ensure the quality of the work provided (mostly) by governmentfunded institutions of higher education.

Another factor influencing accountability is what Trow (1973) called the "massification" of education. This is the move from an elite higher education system serving less than $15 \%$ of the age cohort, to a mass system serving $40 \%$, to a universal system serving over 50\% (Foot \& Stoffman, 1998; OECD, n.d.). The US, UK, Canada, and Australia are now approaching, if not exceeding, the $50 \%$ postsecondary participation rate. With this shift have come new concerns about the capacity of higher education to serve its new (often less prepared) students (Cross, 1971).

Increasingly, calls for accountability are driven by a sense that higher education, 
while enrolling more diverse and larger numbers of students, is falling short of what is needed for citizenship and work in today's global economy. Recent publications in the US, such as Academically Adrift, Our Underachieving Colleges, and Declining by Degrees (Arum \& Roksa, 2011; Bok, 2008; Hersh \& Merrow, 2005, respectively), have questioned the quality of student learning, especially in essential areas such as critical thinking, analytical reasoning, and writing. Not surprisingly, publications like these have caught the attention of national and state policy makers, who in turn have increased pressure for transparency, institutional comparisons, standardized testing, and performance-based funding (Banta, 2010; Clark, 2009; Fain, 2012; National Commission on the Future of Higher Education, 2006; OECD, 2012).

In short, like higher education more generally, the global landscape of accountability is a varied and dynamic one, with a great deal of activity and experimentation, some of it troubling, some more promising. For better or worse, it is part of the context in which SoTL is unfolding today.

\section{PERCEIVED TENSIONS BETWEEN ACCOUNTABILITY AND SOTL}

When Ernest Boyer introduced the term "scholarship of teaching" ("learning" was added later) to higher education in his 1990 report Scholarship Reconsidered, he left the term enticingly open to local definition (Boyer, 1990; Huber \& Hutchings, 2005). His emphasis, however, was clearly on recognizing the intellectual work that went into teaching: the need for teachers to know their subject well, to bring appropriate metaphors and examples to bear, and to develop an attitude of inquiry and continuous improvement toward their work in the classroom (Boyer, 1990). In this, and in many of the definitions of SoTL generated in the years that followed, the emphasis was on intellectual work, on learning and teaching as areas for systematic study, and on a process of knowledge building. This framing clearly contributed to the attraction that SoTL has had for many academics, who connect through it, across national borders, both as committed teachers and as professional scholars (see for instance, Connected Science, Ferrett, Geelan, Schlegel, \& Stewart, 2013, a collection of studies by science faculty from the US, Ireland, and Australia).

The desire to catalyze improvement has no doubt been the intent behind many policies and practices put in place in the name of accountability as well, but, as is often the case, mandates from outside the academy can be perceived as foreign, unfriendly, and bureaucratic. Thus, while SoTL has been associated with grass-roots faculty work and values, accountability has typically been seen as focused on evaluation (and comparability) and external monitoring of outcomes in order to maintain quality. Human tendencies to categorize and simplify (i.e., form stereotypes) have sometimes led academics to a polarized view of the two movements, as illustrated in Table 1.

Whereas accountability and its various quality assurance "cousins" (assessment, accreditation, program review, performance funding, and so forth) have typically been seen as top down, originating mainly from outside academe and driven by questions about efficiencies and resources, SoTL has been described as bottom up and driven by faculty questions and an intellectual impulse (Hutchings, Huber, \& Ciccone, 2011). Not surprisingly, then, and especially because SoTL is still a fragile enterprise, some educators worry that it will be put at risk by the forces of accountability, deforming it and undercutting the scholarly impulse behind it. Those concerns take a variety of forms. 
Table 1. Stereotypical Views of Accountability and SoTL

\begin{tabular}{ll} 
ACCOUNTABILITY & SCHOLARSHIP OF \\
\hline Externally mandated, required & TEACHING AND LEARNING \\
\hline Administratively driven & Internally motivated, voluntary \\
\hline Purpose: evaluation & Faculty driven \\
\hline Focused on reporting & Purpose: inquiry \\
\hline Often standardized (for comparability) & Focused on knowledge-building \\
\hline Institutional or national outcomes & Multiple approaches \\
\hline Linked to resources and productivity & Classroom-based outcomes (typically) \\
\hline Instrumental & Linked to practice and improvement \\
\hline
\end{tabular}

\section{Issues of control}

Faculty who would otherwise be attracted to SoTL may, in a context of accountability, be put off by a sense that it has or will come under the control of an administrative agenda. This was vividly captured by the experience of a campus in the US, the identity of which we agreed to protect, where SoTL was identified with an institutional assessment mandate and therefore resisted ("just say no") by the faculty union. It is captured, too, by comments from those who, while wanting upper-level administrative support for the work, acknowledge that requiring SoTL would be "the kiss of death" (Ciccone, Huber, Hutchings, \& Cambridge, 2009).

\section{Limits of free inquiry and institutional silencing}

The concerns regarding limitations on free inquiry and institutional silencing both tap into expectations of academic freedom held by many faculty. Restriction of lines of inquiry parallel the situation of the journalist who is asked to find evidence to support a story that has already, in some sense, been shaped, rather than being given free rein to uncover an emergent story. For example, at an anonymous US campus with an institutional honor code, a study of student cheating behavior was not permitted. Even if a study is permitted, another concern is that the findings may fall prey to institutional silencing. Two key principles of SoTL are that it begins with faculty members' questions about their own students' learning, whether that be in their own classes or in a larger program of study, and that scholarly dissemination is part of the process. Scholars of teaching and learning knowingly take risks when they explore what their students are and are not learning and then go public with that information (Bass, 1999). They take these risks because the goal is better understanding and, ultimately, improvement of student learning in their classes through a process of modifying approaches, collecting data, and determining impact. However, it's not hard to imagine that those questions, and the insights and findings from them, might conflict with the story the institution wants to tell to accreditors, to parents, and to funders. And when that happens, there are concerns about whose story will prevail-and with what consequences for faculty members whose stories are not the preferred ones. 


\section{No one's listening}

As noted by several faculty members in sessions at the 2012 conference of the International Society for the Scholarship of Teaching and Learning (ISSOTL), those making decisions and policy about educational matters often are not aware of or do not listen to the advice of scholars of teaching and learning. In this way, the larger context of accountability can include signals that the work is irrelevant or without significance. This lack of acknowledgement and perceived impact is hardly a circumstance likely to encourage faculty engagement.

Taken together, these concerns constitute serious cautions. It is hard to know how widespread they are, but they were identified in responses to a 2009 survey of participants in the Carnegie Academy for the Scholarship of Teaching and Learning, case studies solicited for this paper from the Professional and Organizational Development (POD) network, discussions with colleagues about drafts of this paper, and our own "ear to the ground" experiences as observers of and participants in the SoTL movement and its various events.

These concerns must be taken seriously. SoTL will falter without its core identity in faculty curiosity about and passion for their students' learning. For SoTL to flourish, this core identity needs to be preserved even in the face of tensions and counterforces posed by, or perceived from, current calls for accountability. However, as the two movements undergo transformations and developments, it is possible to see the potential for complementarity in the future.

\section{PROMISING DEVELOPMENTS AND CONVERGENCES}

While SoTL continues to be a fragile enterprise in some settings (Renc-Roe, 2012), it is weaving its way into the fabric of campus life in a growing number of places. It has affected teaching, institutional policies and culture, curriculum, faculty development, and assessment initiatives (Hutchings et al., 2011). Recently, for instance, in an international survey of scholars of teaching and learning undertaken by Poole and Simmons (2013), $35 \%$ of respondents reported that their work had influenced policy decisions at their campus, and 53\% thought their research had influenced decisions regarding the nature of educational programs.

Many campuses have made a place not only for individual scholars to explore learning in their classrooms, but also for collaborative work by groups of scholars focused on aspects of learning linked directly to shared outcomes that are the focus of larger quality agendas. At Mount Royal University in Calgary, Ontario, for instance, faculty members are collaborating to study "critical reading" in four different first-year foundation courses. Their collaboration entails a shared definition (critical reading is defined as reading for academic purposes and for social engagement), common methods and sources of evidence, and a jointly designed rubric for analyzing results (Carey, Gale, Manarin, \& Rathburn, 2010).

Work beyond the individual classroom has also taken root at the Unites States Air Force Academy where a "ground up" series of SoTL projects initiated by interested faculty has focused on the institutional outcome of critical thinking. A growing group of faculty members who oversee first-year core courses are working together to create common resources, implement critical thinking development more explicitly and pervasively in and 
across courses, and assess the impact of those efforts. The success of these efforts led a senior administrator to note that the SoTL approach to assessment would be a good one to encourage for other institutional outcomes (Scharff, 2013).

In other settings, SoTL is taking root in part through the involvement of students (Werder \& Otis, 2010). Such arrangements have been documented by Healey (2012) in a wide variety of national settings and models, ranging from students as pedagogical consultants, to co-designers of courses, to fully-fledged practitioners of SoTL. In this way, SoTL is beginning to make a place for itself in the fabric of the institution, not as a special initiative or as a boutique project undertaken by a few faculty, but as a set of practices that can be harnessed to central institutional goals and agendas for student learning and success (Hutchings et al., 2011). As such, it is a practice through which higher education can be accountable to those it directly serves.

Accountability is also undergoing changes, some of which appear to be congruent with the principles of SoTL. For instance, the Voluntary System of Accountability (VSA) in the US, through which campuses publicly post a variety of data, recently expanded its set of allowable assessment measures to include richer forms of evidence about student learning, including student e-portfolios linked to nationally-developed rubrics for key student learning outcomes (Voluntary System of Accountability, 2012). Previously the VSA included primarily standardized forms of information (Jankowski et al., 2012).

In Australia, the Government Office for Learning and Teaching (OLT) is responsible for promoting and supporting "change in higher education institutions for the enhancement of learning and teaching" (Australian Government Office for Learning and Teaching, n.d.a). The Australian Learning and Teaching Council (ALTC) — now recast as a component part of the OLT-initiated a project to determine Learning and Teaching Academic Standards. Many discipline-based scholars, most of whom are active in the SoTL arena, have been leading voices in this project, identifying outcomes for groups of related disciplines. These scholars have successfully proposed, undertaken, and published a diverse set of studies examining effective ways of teaching and learning these outcomes (Australian Government Office for Learning and Teaching, n.d.b). Such work is occurring in a wide array of disciplines and across disciplinary boundaries with a resulting resource of good practice reports. See for example the disciplinary report Learning and Teaching Academic Standards Resources for Law (Kift \& Israel, 2011) or the interdisciplinary Good Practice Report: Blended Learning (Partridge, Ponting, \& McCay, 2011).

In Scotland, the Quality Assurance Agency employs a quality enhancement approach—called Enhancement-Led Institutional Review (ELIR) - that is explicitly in the service of improvement. For most of the last decade, it has been framed around enhancement-led themes, for instance the giving of marks and feedback to students, employability, linking teaching and research, and graduate attributes (Quality Assurance Agency for Higher Education, n.d.). Though the term is not used, the ELIR has funded SoTL-type projects designed to examine these themes conceptually and to identify examples of good practice (i.e., "things that make a difference") both within Scotland, and beyond, with the aim of enhancing teaching and learning practices (Lines, 2010).

Shifts in approaches to accountability are afoot in Canada as well. Though systems of accountability vary across provinces, for the past 40 years or so most have focused on research productivity more than educational quality. But a number of factors have begun to change this balance. Influenced by the Bologna process, Ontario universities are now 
required to meet mandated degree-level expectations (Ontario Ministry of Training, Colleges and Universities, n.d.). However, the early involvement of teaching and learning centers is helping to turn this from a top-down imposition of standards to an opportunity for discussion and engagement regarding shared goals (Hubball \& Gold, 2007). This collaboration can result in articulation of faculty-defined, discipline-specific learning outcomes, which nicely lend themselves to inquiry through SoTL.

\section{BUILDING BRIDGES}

As the previous section suggests, the distance between SoTL and accountability, while still evident in many contexts, is lessening, and there are now significant opportunities to build bridges between the two movements. One important set of bridge-building opportunities lies in the role that scholars of teaching and learning can play as mediators and translators. As we have argued in this paper, those involved in pedagogical inquiry (most often faculty members), in developing institutional evidence of student learning (institutional researchers and administrators), and in accountability initiatives (accreditors and government policy makers) often share a common interest: improving student learning outcomes at the classroom, institutional, or national level. Unfortunately, these groups rarely interact in a setting that promotes discussion of shared goals, and often talk in ways that do not promote their common interests. Worse, they often view each other as adversaries, perpetuating and widening divisions. However, by focusing on the shared goal of improving student learning, these divisions can be bridged.

Scholars of teaching and learning, because of their intentional and systematic approach to analyzing, documenting, and sharing student learning outcomes, have a unique role to play in this bridge-building process. In essence, they can serve as mediators or translators of external accountability mandates, helping both university administrators and faculty members develop a richer, more complex understanding of student learning that not only promotes continuous improvement, but also makes visible to external stakeholders the learning achieved by the institution's students.

We see this dynamic in the case of Unitec Institute of Technology in New Zealand. In recent years, the New Zealand government has focused strategic attention on the enhancement of adult literacy and numeracy. This has been accompanied by substantial government funding and associated accountability requirements focusing on learner participation and evidence of learner progression. Typically, the evidence required has been in the form of quantitatively measured learner outcomes. However, at Unitec, the centralized Academic Literacies team noted these demands and set about taking a SoTL approach to supplement the required quantitative measures and to enhance teacher capability. The team formed an action research group with teachers from across the institution to explore ways to achieve sustainable change in literacy embedding. This initiative immediately shifted the focus from externally imposed accountability to internally owned improvement. Unitec's experience nicely illustrates the benefits of translating an external accountability mandate into terms that align with the principles and practices of SoTL.

Examples of this kind of bridge building appear in other settings as well. For instance, at the University of Cincinnati, Theresa Berry, director of the Center for Educational Research in the College of Nursing, notes, "There is no support for SoTL work unless it is clearly linked to accountability efforts for the institution" (personal communication). Accordingly, the university explicitly (and successfully) drew on work from its SoTL ini- 
tiative to support its reaccreditation efforts (Hutchings et al., 2011). A different type of translation has emerged at Loyola Marymount University, where "faculty who asked and attempted to answer SoTL questions have had to gather evidence that goes beyond grades on assignments and tests, and they have done so systematically. As a result they have very likely developed a skill-set that would be useful in assessment" (Dewar, 2008, p. 21).

Scholars of teaching and learning also have the ability to better connect accountability efforts with the everyday work and interests of faculty members. Accountability and related terms ("assessment" in the US, for instance, and even "quality" in some settings) are "four-letter words" for many academics, while SoTL, a more bottom-up practice, taps into faculty members' natural interest in their own students and their learning, and draws on their habits and skills as scholars. Fitting in more naturally with academic culture, SoTL has the power to attract faculty in ways that other practices may not. As a result, using SoTL as a route into institutional assessment and accountability is likely to generate greater buy-in by faculty members than top-down accountability mandates alone.

In addition, and as noted in a previous section of this paper, students can be actively involved in SoTL - and their involvement can often serve as a further context for bridge building. A well-developed example occurs at North Carolina A\&T State University, where students who are part of the Wabash-Provost Scholars program conduct focus group sessions with their peers, obtain and analyze qualitative and quantitative data, develop written summary reports, and lead scholarly presentations on their work and experiences (Hutchings et al., 2011). Involving students has helped the institution connect highlevel questions (e.g., how to improve student learning outcomes in gateway mathematics courses) to on-the-ground experience by students in ways that have led to institutional course redesign and pedagogical innovation initiatives, among others (Baker, 2012). In addition, this kind of involvement is good for students, engaging them very directly in reflections on their learning and how to improve it - and that is a goal that both the agents of accountability and scholars of teaching and learning can fully embrace.

\section{RECOMMENDATIONS TO THE SOTL COMMUNITY}

Overall, our view is that focusing on the common goal of improving student learning outcomes offers the potential for positive synergy between accountability and SoTL. As noted at the beginning of this paper, we have chosen to explore our topic broadly, seeking to lay out a diverse array of issues. But in this final section, our intent is to focus more narrowly on what is implied for scholars of teachings and learning-which is to say the readers of this journal. We have five recommendations.

\section{Open communication channels with others on campus}

Gathering, analyzing, and sharing evidence of student learning is a practice that occurs in many places on most campuses, be it through institutional research, offices of assessment, the accreditation process, initiatives like writing across the curriculum, program review, or SoTL. Too often, these groups do not talk to one another in any systematic fashion (Hutchings et al., 2011; Poole \& Simmons, 2013). Our first and overarching recommendation is that communication lines be opened. We believe that scholars of teaching and learning can take the lead in making this happen, serving as conversation starters, mediators, and translators. 


\section{Encourage collaborative work}

There should always be a place for individual faculty to explore their own questions about students in their classrooms, but we are also arguing for the importance of building SoTL communities to explore broader questions that align with institutional improvement agendas. We have noted several instances of such work, including studies of critical reading at Mount Royal University, and of critical thinking at the United States Air Force Academy. Examples like these show faculty collaborating on projects that have intrinsic interest to individual scholars while also informing work on broad, institutional learning goals and strategic directives (like retention) that are a focus of accountability.

\section{Reach out to new audiences}

As individual scholars of teaching and learning, we are often interested in very specialized aspects of our students' learning. Part of our responsibility (as in other forms of research) is to translate that specialized work into terms that are meaningful to a broader audience, including those who make policy and shape the mechanisms of external accountability within our institutions (Weingarten, 2012). ISSOTL and other SoTL-related groups can take direct roles in this work and partner with organizations that interact with policy makers. Further, as we engage in such outreach we need to hold ourselves to the high standards established for SoTL in order to be seen as a credible source of information and insight.

\section{Involve students}

Continuing to involve students in SoTL is a necessary step in ensuring that both SoTL and accountability are focused on improving the quality of student learning. The link between high-level accountability questions and student experience is critical and needs to continue to be nurtured.

\section{Educate ourselves and others}

In general, the SoTL community would do well to provide opportunities (for instance at conference sessions) for its members to learn about accountability, quality assurance, assessment and accreditation, and to strategize about how to build bridges with the work going on under those different, respective banners, be it in policy circles beyond the campus or in conversations with colleagues and students in their own institutions in ways that bring common purpose more clearly into view.

\section{CONCLUSION}

Reviewing the current state of accountability and SoTL, it seems clear that neither movement has yet achieved its full potential for broadly and meaningfully improving the learning outcomes of students. In the case of the former, many campuses are remarkably successful in going through the motions required by accountability mandates without engaging in real change (Banta \& Blaich, 2011; Blaich \& Wise, 2011). In the case of SoTL, while participants often report deep transformational experiences (Cox, Huber, \& Hutchings, 2005; Sommers, 2004), the number of participants in most settings is still small, and changes are necessarily limited.

Perhaps, then, these two movements, coming from different directions, can strengthen 
what is best in each other. Accountability, with its growing focus on more and better information about student learning, can provide an occasion and context for doing and valuing SoTL. SoTL, rooted in the classroom and driven by faculty, can help connect high-level accountability processes back to practice where they can make a difference in the lives and learning of students. Rather than letting the perceived differences in these movements create conflict and distrust, we believe the time has come to work together more intentionally and systematically, building on positive synergies to create an educational experience worthy of students' investment.

Pat Hutchings is a Consulting Scholar for the Carnegie Foundation for the Advancement of Teaching, and Scholar in Residence at Gonzaga University, Washington, USA.

Paola Borin is a Curriculum Development Consultant at Ryerson University, Ontario, Canada.

Linda Keesing-Styles is Dean of Teaching and Learning at Unitec Institute of Technology, Auckland, New Zealand.

Lynn Martin is a McMaster University Teaching Fellow and Assistant Professor in the School of Nursing at McMaster University, Ontario, Canada.

Renee Michael is Director of the Center for Teaching Excellence and Professor of Psychology at Rockhurst University, Missouri, USA.

Lauren Scharff is the inaugural Director for the SoTL Program and Professor in the Department of Behavioral Sciences and Leadership at the U.S. Air Force Academy, Colorado, USA.

Scott Simkins is Director of the Academy for Teaching and Learning and Associate Professor of Economics at North Carolina A\&T State University, North Carolina, USA.

Ahmed Ismail is a Ph.D. student in the Department of Sociology at McMaster University, Ontario, Canada.

\section{REFERENCES}

Arum, R., \& Roksa, J. (2011). Academically adrift: Limited learning on college campuses. Chicago: University of Chicago Press.

Australian Government Office for Learning and Teaching. (n.d.a). About the office for learning and teaching. Retrieved April 9, 2013 from http://www.olt.gov.au/about-olt.

Australian Government Office for Learning and Teaching. (n.d.b). The discipline scholars. Retrieved April 9, 2013 from http://www.olt.gov.au/june2010-discpline-scholars.

Baird, J. (2011). Accountability in Australia. In B. Stensaker, \& L. Harvey, (Eds.), Accountability in higher education: Global perspectives on trust and power. New York: Routledge.

Baker, G. R. (2012). North Carolina A\&T State University: A culture of inquiry. (NILOA Examples of Good Assessment Practice). Urbana, IL: University of Illinois and Indiana University, National Institute for Learning Outcomes Assessment.

Banta, T.W. (2010). Impact of addressing accountability demands in the United States. Quality in Higher Education, 16(2), 181-183.

Banta, T.W., \& Blaich, C. (2011). Closing the assessment loop. Change: The Magazine of Higher Learning, 43(1), 22-27. 
Bass, R. (1999). The scholarship of teaching and learning: What's the problem? Inventio: Creative Thinking About Learning and Teaching, 1(1), 1-10.

Blaich, C. F., \& Wise, K. S. (2011). From gathering to using assessment results: Lessons from the Wabash National Study (NILOA Occasional Paper No.8). Urbana, IL: University of Illinois and Indiana University, National Institute for Learning Outcomes Assessment.

Bok, D. C. (2008). Our underachieving colleges: A candid look at how much students learn and why they should be learning more. Princeton, N.J.: Princeton University Press.

Boyer, E. L. (1990). Scholarship reconsidered:Priorities of the professoriate. Princeton, N. J.: The Carnegie Foundation for the Advancement of Teaching.

Brown, P., \& Lauder, H. (1996). Education, globalization and economic development. Journal of Education Policy, 11(1), 1-25.

Carey, M., Gale, R., Manarin, K., \& Rathburn, M. (2010, November). Critically reading the word and the world. Presentation at the Centennial Symposium on Scholarship of Teaching and Learning, Banff, AB, Canada, Nov. 2010.

Ciccone, A., Huber, M. T., Hutchings, P., \& Cambridge, B. (2009). Exploring impact: $A$ survey of participants in the CASTL institutional leadership and affiliates program. Stanford, CA: The Carnegie Foundation for the Advancement of Teaching.

Clark, T. (2009). Impact of reforms on the quality and responsiveness of universities in the United Kingdom. Higher Education Management and Policy, 21(2), 107-122.

Cox, R., Huber, M. T., \& Hutchings, P. (2005). Survey of CASTL scholars. In M. T. Huber and P. Hutchings, The advancement of learning: Building the teaching commons (133-149). San Francisco: Jossey-Bass.

Cross, K. P. (1971). Beyond the open door: New students in higher education. San Francisco: Jossey-Bass.

Dewar, J. M. (2008). An apology for the scholarship of teaching and learning. InSight: A Journal for Scholarly Teaching, 3,17-22.

Fain, P. (2012). Performing under pressure. Inside Higher Education, October 22, 2012. Retrieved January 7, 2013 from http://www.insidehighered.com/news/2012/10/22/bettermeasures -college-performance.

Ferrett, T. A., Geelan, D., Schlegel, W. M., \& Stewart, J. L. (Eds.). (2013). Connected science: Strategies for integrative learning in college. Bloomington, IN: Indiana University Press.

Foot, D. K., \& Stoffman, D. (1998). Boom, bust \& echo 2000: Profiting from the demographic shift in the new millennium (Rev. ed.). Toronto: Macfarlane Walter \& Ross.

Healey, M. (2012). Students as change agents. Retrieved January 7, 2013 from http://www .mickhealey.co.uk/resources.

Hersh, R. H., \& Merrow, J. (2005). Declining by degrees: Higher education at risk. New York: Palgrave Macmillan.

Hubball, H., \& Gold, N. (2007). The scholarship of curriculum practice and undergraduate program reform: Integrating theory into practice. New Directions for Teaching and Learning, 2007(112), 5-14.

Huber, M. T., \& Hutchings, P. (2005). The advancement of learning: Building the teaching commons. San Francisco: Jossey-Bass. 
Hutchings, P., Huber, M. T., \& Ciccone, A. (2011). The scholarship of teaching and learning reconsidered: Institutional integration and impact. San Francisco: Jossey-Bass.

International Organization for Standardization (ISO). (2012). Standards. Retrieved December 31, 2012 from http://www.iso.org/iso/home/standards.htm.

Jacobi, M., Astin, A.W., \& Ayala, F. (1987). College student outcomes assessment: A talent development perspective (J-B ASHE Higher Education Report Series (AEHE)) (1sted.).San Francisco: Jossey-Bass.

Jankowski, N. A., Ikenberry, S. O., Kinzie, J., Kuh, G. D., Shenoy, G. F., \& Baker, G. R. (2012). Transparency \& accountability: An evaluation of the VSA college portrait pilot. Urbana, IL: University of Illinois and Indiana University, National Institute for Learning Outcomes Assessment.

Kift, S., \& Israel, M. (2011). Learning and teaching academic standards resources for law. Strawberry Hills, NSW: Australian Learning and Teaching Council.

Lines, D. (2010). Enhancement themes: Things that make a difference: Lessons from the enhancement themes. Manchester: The Quality Assurance Agency for Higher Education. Retrieved April 9, 2013 from http://www.enhancementthemes.ac.uk.

Marchese, T. (1991). TQM reaches the academy. American Association for Higher Education Bulletin, 44(3), 3-9.

National Commission on the Future of Higher Education. (2006). A Test of leadership: Charting the future of US higher education. Washington, D.C.: GPO.

Newton, J. (2000). Feeding the beast or improving quality? Academics' perceptions of quality assurance and quality monitoring. Quality in Higher Education, 6(2), 152-163.

Organization for Economic Co-operation and Development (OECD). [n.d.]. Higher education and adult learning: Testing student and university performance globally. Retrieved December 11, 2012 from http://www.oecd.org/education/highereducationandadultlearning /testingstudentanduniversityperformancegloballyoecdsahelo.htm.

Organization for Economic Co-Operation and Development (OECD). (2012). Education at a glance 2012: OEDC indicators, OECD publishing. Retrieved January 7, 2012 from http://dx .doi.org/10.1787/eag-2012-en.

Ontario Ministry of Training, Colleges and Universities. (n.d.). Ontario qualifications framework (OQF). Retrieved April 9, 2013 from http://www.tcu.gov.on.ca/pepg/programs/oqf.

Partridge, H., Ponting, D., \& McCay, M. (2011). Good practice report: Blended learning. Strawberry Hills, NSW: Australian Learning and Teaching Council.

Poole, G. \& Simmons, N. (2013). Contributions of the scholarship of teaching and learning to quality enhancement in Canada. In R. Land \& G. Gordon (Eds.), Enhancing quality in higher education: International perspectives. London: Routledge.

Quality Assurance Agency for Higher Education. (n.d.). Welcome to the enhancement themes website. Retrieved April 9, 2013 from www.enhancementthemes.ac.uk/.

Renc-Roe, J. (2012, October). SOTL travels: Furthering the potential of the scholarship of teaching and learning. Presentation at the International Society for the Scholarship of Teaching and Learning, Hamilton, ON, Canada.

Scharff, L. (2013). Getting at the big picture through SoTL. In K. McKinney (Ed.), The schol- 
arship of teaching and learning in and across the disciplines. Bloomington, IN: Indiana University Press.

Sommers, J. (2004). Two-year college English faculty and the scholarship of teaching and learning: The journey awaits. Teaching English in the Two-Year College, 32, 14-25.

Stensaker, B., \& Harvey, L. (2011). Accountability in higher education: Global perspectives on trust and power. New York: Routledge.

Trow, M. (1973). Problems in the transition from elite to mass higher education. Berkeley, CA: Carnegie Commission on Higher Education Reprint.

Voluntary System of Accountability. (2012). Voluntary System of Accountability (VSA) administration and reporting guidelines: AAC\&U VALUE rubrics - demonstration project. Retrieved January 7, 2013 from www.voluntarysystem.org/news

Weingarten, H. P. (2012, October). Integrating the scholarship of teaching and learning into the academy. Presentation at the International Society for the Scholarship of Teaching and Learning, Hamilton, ON, Canada.

Werder, C., \& Otis, M. M. (Eds.). (2010). Engaging student voices in the study of teaching and learning. Virginia: Stylus. 